\title{
CARREIRA, MERCADO DE TRABALHO E AS LIÇÕES DE “DONANA" NO PROCESSO DE ENSINO- APRENDIZAGEM E PESQUISA EM ADMINISTRAÇÃO
}

\author{
1- Iraides Gonçalves do Amaral* \\ Mestranda em Gestão de Projetos pela Universidade Nove de Julho (UNINOVE), Brasil. \\ Professora de Graduação em Administração da Universidade Nove de Julho (UNINOVE), Brasil. \\ iraides@uninove.br \\ http://lattes.cnpq.br/9032652986677305
}

\section{2- Nildes R. Pitombo Leite}

Doutora em Administração pela Universidade de São Paulo (FEA-USP), Brasil.

Professora de Pós Graduação em Administração da Universidade Nove de Julho (UNINOVE), Brasil. nildespitombo@uninove.br

http://lattes.cnpq.br/1050030810573625

\section{3- Eline Dias Moreira}

Doutoranda em Matemática pela Universidade Bandeirante de São Paulo (UNIBAN), Brasil. Professora de Graduação em Administração da Universidade Nove de Julho (UNINOVE), Brasil. eline@uninove.br

http://lattes.cnpq.br/9772535076327018

\section{4- Miriam Assunção Tazem Salgueiro}

Especialista em Recursos Humanos pela Universidade Nove de Julho (UNINOVE), Brasil. Professora de Graduação em Administração da Universidade Nove de Julho (UNINOVE), Brasil. miriam_tazem@uninove.br

http://lattes.cnpq.br/2913942973277104 


\section{CARREIRA, MERCADO DE TRABALHO E AS LIÇÕES DE “DONANA" NO PROCESSO DE ENSINO-APRENDIZAGEM E PESQUISA EM ADMINISTRAÇÃO}

\section{RESUMO}

O objetivo geral desta pesquisa é investigar a contribuição do teatro para o processo de ensinoaprendizagem em Administração. Justifica-se, sobretudo, pelos aspectos contidos na indissociabilidade, entre ensino, pesquisa e extensão, aqui considerados relevantes. Contextualiza-se que ela foi realizada à luz do texto de "DonAna", como base para análise da dinâmica entre as lições mostradas nesse espetáculo e a formação dos discentes em recursos humanos, na perspectiva de reflexão sobre carreira, mercado de trabalho e velhice. Os dados primários foram coletados por meio de entrevista em profundidade com o autor/ator da peça; questionário aberto e semiestruturado em uma survey de experiência com 107 discentes envolvidos no processo de ensino-aprendizagem com essa peça; um grupo focal com 11 discentes que também assistiram à peça e fizeram exercícios em sala de aula. A participação desses 118 discentes ocorreu com todos eles oriundos do curso de Administração de Recursos Humanos de uma universidade privada da cidade de São Paulo. Todos esses dados foram analisados pela técnica de análise dos conteúdos das mensagens. Os resultados indicam a contribuição do teatro para o processo de ensinoaprendizagem em Administração em cada uma das vertentes: ensino, pesquisa e extensão.

\section{Palavras-Chave}

Administração de Recursos Humanos; Arte-Educação; Ensino-Aprendizagem.

\section{CAREERS, WORK MARKET AND THE LESSONS OF "DONANA" IN THE TEACHING-LEARNING PROCESS AND ADMINISTRATION RESEARCH}

\section{ABSTRACT}

The objective of this research is to investigate the contribution of the theater for the teaching-learning in Administration. Justified, especially for aspects contained in the inseparability between teaching, research and extension, as relevant here. Contextualizes it held against the background of the "DonAna", as a basis for analysis of the dynamics between the lessons shown in this show and the training of students in human resources with a view to reflecting on career, employment and old age. Primary data were collected through in-depth interview with the author / actor of the script; open and semi-structured questionnaire in a survey of experience with 107 students involved in the teaching-learning process with this text, a focus group with 11 students who also seen the play and did exercises in the classroom. The participation of 118 students with all of them came from the training course in Human Resource Administration of a private university from the city of São Paulo. All data were analyzed using analysis of message contents. The results indicate the contribution to the theater to the teaching-learning in Administration in each of the strands: teaching, research and extension.

\section{Keywords}

Human Resources Administration; Art and Education; Teaching and Learning. 


\section{Introdução}

Tomando-se por premissa o exercício da indissociabilidade entre ensino, pesquisa e extensão como a base na qual a universidade deve ser sustentada e que: a vertente mais forte, no processo de ensinoaprendizagem, é a socialização do conhecimento, na pesquisa, a produção do conhecimento e, na extensão, a aplicação desse conhecimento, parte-se da premissa que se precisa entender porque ensinar e aprender devem ser fonte de inspiração e motivação tanto para discentes quanto para docentes.

Nessa fonte de inspiração, a escolha de métodos educacionais alternativos pode envolver as artes, como mostram Wood Jr (2000); Duarte (2002); Vergara (2003); Vergara (2007); Almeida (2004); Brandão (2004); Costa (2004); Davel, Vergara, Ghadiri \& Fischer (2004); Davel, Vergara \& Ghadiri (2007); Koudela \& Santana (2005); Leite, N. R P \& Leite (2007); Vergara, Davel \& Ghadiri (2007); Ipiranga (2007); Taylor (2007); Cavassin (2008); Napolitano (2009); Leite, N. R P \& Leite (2010); Leite, N. R P Nishimura \& Leite (2010); Leite, N. R P, Leite, Nishimura \& Cherez (2010). Davel, et al.(2007, p. 14) afirmam:

quando pensamos na dimensão estética do ensino-aprendizagem da administração, pensamos na dimensão do sentimento e da experiência perceptiva que é desenvolvida por meio dos sentidos. A experiência estética envolve um esforço que ativa as faculdades do sentido e afia a percepção de fenômenos físicos. Engaja, então, as pessoas em suas experiências sensíveis, como as sensoriais, sensuais e cognitivas.

Por meio dessa dimensão estética, o discente pode conseguir desenvolver sentidos de percepção da linguagem sob uma ótica diferente do contexto cotidiano de sala de aula e tornar-se capaz de aprender a aprender de forma diferenciada. Costa (2004) questiona se, por si só, uma arte já não seria educativa e, o que seria, de fato, a nova abordagem, que preconiza a arte e a ludicidade como elementos catalizadores dos processos de ensino- aprendizagem?

Privilegia-se, nesta pesquisa, a premissa que os discentes aprendem quando são emocionalmente tocados. Respaldam tal premissa: Dewey (1934), quando já argumentava acerca da arte e da estética como desenvolvimentos refinados do desejo fundamental do ser humano de atribuir sentido e valor à vida. Nesses termos, há o reforço de que, devido ao seu caráter estético a experiência constitui uma unidade, na qual a obra artística pode concentrar e ampliar a experiência vivida por esse ser humano; Abbs (1994), ao defender que poder pensar na arte como recurso pedagógico, em consequência pode remeter à dinâmica dos sentimentos e ao inconsciente humano; Davel et al. (2007, p.18) ao advogarem que: "[ ...] para construir de forma alternativa ou enriquecedora o que as organizações e a adminsitração são para os estudantes, necessitamos nos voltar para outros discursos ou vocabulários que carregarão a experiência que desejamos suscitar"; Goodman (1976) ao ensejar a diferença entre as aulas expositivas, nas quais são mobilizadas as linguagens (falada e escrita) e a utilização da arte em salas de aula, em que é aberto espaço para outros tipos de linguagem como visual, musical, corporal e sonora.

No que se relaciona especialmente às artes cênicas, Costa (2004) relembra a importância do teatro como instrumento da pedagogia jesuítica nos primórdios da educação brasileira. Koudela \& Santana (2005) ampliam tal afirmação, quando dizem que os pressupostos epistemológicos de uma metodologia do ensino necessitam proporcionar o conhecimento da estrutura teórico-prática dos procedimentos que levam à aprendizagem, não somente na esfera do teatro, como em qualquer outra área do conhecimento.

Em tais discussões e, para o processo de ensino-aprendizagem, Luckesi (2002) convida a considerar-se o ganho, haja vista, que o lúdico e a arte contemplam o político, o afetivo, e estético, a ética, a crítica e a inteireza na relação humana, partindo do pressuposto de que a educação precisa dessa inteireza e da plenitude nesse processo. Cavassin (2008, pp. 48-49) diz que o teatro “[ ...] pode ser a brecha que se abre na nova perspectiva da ciência e ensino-aprendizagem [...] nessa brecha está o desafio das artes na produção do conhecimento, rompendo com o padrão que por tanto tempo inferiorizou o status científico da arte na história do conhecimento [ ....".

Assim, por meio da integração ao projeto pedagógico, como princípio educativo que atravessa a formação do discente em sala de aula e nas tarefas acadêmicas, ampliando-lhes os campos de ação, de reflexão e de autonomia intelectual, os discentes têm oportunidade de entrar em contato com a pesquisa.

Propicia-se, portanto, o exercício da indissociabilidade, pela consolidação do ensino, da pesquisa e da extensão, dentre outras, por necessidade de: formação profissional; o discente identificar-se culturalmente e referenciar a sua futura prática; utilizar uma metodologia de ensino (com compromissos epistemológicos, pedagógicos, éticos e sociais) que pode tornar possível a exploração da aprendizagem, por meio das peças teatrais que venham a contribuir para uma educação voltada para a vida de forma plena. 
Justifica-se esta pesquisa, sobretudo, pelos aspectos contidos na indissociabilidade, entre ensino, pesquisa e extensão, aqui considerados relevantes. Relembra-se que ela foi inicialmente planejada a partir da vertente do ensino, por intermédio de uma ação cultural que pôde favorecer ao discente a compreensão de conteúdos aplicados em sala de aula, associados ao contexto analisado no espetáculo "DonAna", além da análise da dinâmica entre as lições mostradas nesse espetáculo e a formação dos discentes em recursos humanos, na perspectiva de reflexão sobre carreira, mercado de trabalho e velhice. Enfatiza-se que o objetivo geral desta pesquisa é investigar a contribuição do teatro para o processo de ensino-aprendizagem em Administração. Dessa forma, a questão que se busca responder é assim enunciada: Como o teatro pode contribuir para o processo de ensino-aprendizagem e pesquisa em Administração?

\section{O Contexto da Carreira, do Mercado de Trabalho e da Velhice}

No que tange ao contexto da carreira, faz-se imprescindível iniciar esta fundamentação teórica pela origem da expressão, segundo Martins (2001) e (Chanlat, 1995, p. 68-69), para quem

etimologicamente a palavra carreira se origina do latim medieval via carraria, que significa estrada rústica para carros. Mas o conceito de carreira, tal qual o conhecemos hoje, como a trajetória de vida profissional é recente, tendo aparecido no século XIX. A palavra quer dizer 'um ofício, uma profissão que apresenta etapas, uma progressão.

A questão dessa progressão dos indivíduos em uma organização é importante para ampliação e manutenção de seu diferencial competitivo. As organizações estão pressionadas pelos indivíduos que a compõem e pelo ambiente externo para investir no desenvolvimento humano, pois esses indivíduos buscam certa segurança no mercado de trabalho. Eles necessitam ser preparados para enfrentar contextos cada vez mais complexos e, o desenvolvimento, em cada uma das etapas em dada progressão, encontrase associado a essa complexidade advinda dos avanços tecnológicos e das relações de trabalho.

Nesse contexto London \& Stumph (1982) afirmam a clareza dos papeis e responsabilidades do indivíduo e da organização. Iniciando pela perspectiva do indivíduo a carreira engloba o entendimento e a avaliação de suas experiências profissionais. Do lado da organização a carreira organizacional abrange políticas, práticas e decisões ligadas a espaços ocupacionais, níveis hierárquicos, compensação e movimentação de pessoas. Todavia, esses autores lembram que a carreira antes era entendida como uma sequência de posições ocupadas no trabalho ao longo da vida de um indivíduo e envolvia estágios e transições que refletiam necessidades, motivos e aspirações, bem como expectativas e restrições das organizações e da sociedade.

No passado, conforme Evans (1996), a grande maioria das pessoas via, pelo menos em termos convencionais, a carreira como uma escada em que o indivíduo podia iniciar a vida profissional, adquirir estabilidade, promoções e permanecer subindo os degraus rumo ao topo da organização. Desse modo, o jovem, ao ingressar no mercado de trabalho, deveria ir subindo cada degrau, assumindo níveis mais altos de responsabilidades, de status ou de salário. Apesar de essa noção poder vir a persistir no futuro, é importante abordar outras formas de pensar sobre carreira e seu desenvolvimento, formas essas que fazem muito mais sentido em uma organização mais plana.

Nas últimas duas décadas percebem-se mudanças fundamentais no papel do indivíduo diante de sua carreira, dadas a instabilidade e a incerteza do mercado de trabalho. Dito por Magalhães, Martinuzzi \& Teixeira (2004, p.16) "usualmente considera-se que os interesses vocacionais desenvolvem-se a partir de experiências de vida que reforçam o gosto por determinados tipos de atividades mais do que outros".

Assim, acirra-se a consciência de que as carreiras pertencem, em última instância, aos indivíduos e não às organizações e, em consequência, cabe a esses indivíduos a responsabilidade por planejar e buscar seu autodesenvolvimento, seja dentro ou fora do contexto das organizações.

Diante de tais mudanças, Arthur \& Rousseau (1996) chamam a atenção para papeis e responsabilidades que também passaram a ser estabelecidos sob a ótica da carreira sem fronteiras, na medida em que o indivíduo precisa se voltar para a interpretação de sua situação de carreira independentemente do local e do empregador.

Essas argumentações também são vistas em Bianchi \& Quishida (2009), segundo as quais a gestão da carreira pertence às pessoas e cabe a elas a responsabilidade de planejar o que aprender e investir em seu desenvolvimento para conseguir os resultados esperados. Não obstante, as autoras alertam ainda que, 
muitas vezes acontece o indivíduo esperar demais da organização e fazer uma leitura equivocada dos papeis e responsabilidades individuais, estimulado pela cultura organizacional ou por sua própria leitura. Magalhães \& Gomes (2005, p. 73) afirmam que “em resposta à insegurança e à turbulência do mercado atual, muitos trabalhadores têm decidido criar novas alternativas de vida e carreira. Entre essas possibilidades estão a abertura de um empreendimento próprio, a diversificação da capacitação profissional e a mudança de emprego".

Os indivíduos passam, a partir da visão dessas mudanças, a gerir sozinhos, o que outrora era delegado às organizações e posteriormente compartilhado com elas. Um dos recursos com os quais o indivíduo pode contar é a elaboração de um projeto profissional que se subdivide nas etapas sugeridas por Dutra (2002): autoconhecimento; conhecimento do mercado; estabelecimento dos objetivos de carreira; estabelecimento das estratégias de carreira; definição de um plano de ação; acompanhamento do plano de ação.

Tal projeto está indissociavelmente ligado ao planejamento da carreira que, sob a ótica de Magalhães \& Gomes (2005) se refere à disposição para fazer algo com respeito à escolha de uma ocupação e para a permanência do sujeito nessa ocupação, relacionanda-o, portanto, ao efetivo desenvolvimento da carreira. Os autores referem-se, também às preferências vocacionais e suas implicações no modo como os indivíduos conduzem suas carreiras, contibuem socialmente e deixam o seu legado para a posteridade. E, nessas circunstâncias, quando buscam agregar valor à organização ao mesmo tempo em que se desenvolvem na carreira, o papel desses indivíduos se mostra mais amplo e complexo.

Para Stamp (1993), apud Dutra (2011, p. 102) “[...] quando uma pessoa aprende a atuar em determinado nível de complexidade, ela não regride para níveis menores. Ao contrário, quando tem de trabalhar em níveis de menor complexidade, a pessoa sente-se frustrada e não desafiada [...]". Não apenas o conceito de complexidade, mas também os conceitos de carreira e competência são fundamentais para dar embasamento ao desenvolvimento de pessoas. De acordo com Dutra (2011, p. 106),

os principais agentes do Sistema de Adminsitração de Carreiras são as pessoas, a quem cabe gerir sua carreira, e a empresa, a quem cabe estimular e apoiar as pessoas em seu processo de encarreiramento. Para gerir sua carreira, a pessoa necessita conhecer-se, ter consciência de seu projeto profissional e ter conhecimento das oportunidades oferecidas pela empresa e pelo mercado de trabalho [ ...]

Essa concepção está alinhada à de progressão dos indivíduos em dada organização, lembrando ainda que, na visão de Magalhães, Krieger, Vivian, Straliotto \& Poeta (2004, p. 58) “o papel profissional é um dos pilares fundamentais da autoestima, identidade e senso de utilidade".

No que diz respeito ao mercado de trabalho as transformações que ocorrem na constituição das diversas categorias profissionais e de emprego que integram o mercado de trabalho, configuram uma das principais evidências da transição histórica atualmente em curso, caracterizada, principalmente, pela globalização e reestruturação dos sistemas produtivos.

Nas sociedades capitalistas, tomando-se por base Offe \& Hinrich (1984), o mercado de trabalho pode ser entendido como o elo que organiza a relação de troca, contrapondo os que ofertam a força de trabalho com aqueles que a demandam. Pode ainda ser visto como a principal instância na qual ocorre a solução institucional para um duplo problema de alocação: de um lado, o sistema produtivo precisa ser provido com o trabalho necessário para a geração de riqueza; do outro, os indivíduos detentores da força de trabalho necessitam dos meios monetários (salário e benefícios) e sociais (status) para assegurar sua sobrevivência.

Na visão de Araújo, Albuquerque \& Silva, (2009), tanto os empregados quanto os desempregados participam direta ou indiretamente da dinâmica do mercado de trabalho, enquanto que os grupos de inativos e autônomos se encontram em situações nas quais sua força de trabalho não está submetida diretamente aos mecanismos desse mercado.

Ainda de acordo com esses autores, a taxa de migração de trabalhadores autônomos para as categorias de empregados ou desempregados é determinada pelos processos de inovação ou por crises econômicas que refletem no mercado de bens. A passagem do grupo de inativos para a condição de empregado ou desempregado depende de normas legais e aspectos culturais que fixam os limites pessoais de participação no mercado de trabalho, como é o caso da idade mínima para o primeiro emprego. O movimento entre as categorias de empregados e desempregados é motivado por determinantes econômicos da demanda por força de trabalho, como desenvolvimento de novos 
mercados de bens e serviços, racionalização de processos por meio do uso de tecnologias poupadoras de mão de obra, dentre outros.

Associada a outras variáveis de natureza econômica e social a dinâmica do mercado de trabalho finda por gerar, pelo lado da oferta, os chamados representantes de uma parte da população que: fica frequentemente desempregada; encontra maior dificuldade de estabelecer uma relação de emprego formal; facilmente é demitida; percebe menores salários; ocupa postos de trabalho mais restritivos; está exposta a riscos em sua capacidade física e em sua qualificação para o trabalho, sujeita, portanto, a condições mais vulneráveis.

Salienta-se, aqui, o movimento de estruturação do mercado de trabalho brasileiro, caracterizado pela expansão dos empregos assalariados, sobretudo daqueles com registro, e diminuição de ocupações por conta própria, sem registro e do desemprego, foi motivado, de um lado, pela promulgação de todo um arcabouço legal para disciplinar as relações trabalhistas, materializado pela Consolidação das Leis do Trabalho (CLT) e, do outro, pela implantação do projeto nacional de industrialização.

No que concerne à velhice, o tempo é o responsável por formar e nutrir a experiência de toda uma vida, modificar as perspectivas e direções a serem tomadas na trajetória, usufruir escolhas, compreender perplexidades, ansiedades, fascinações, deslumbramentos, desconhecimentos, estranhezas e incertezas, além de possibilitar contribuições para orientações dos mais jovens. Assim, Monteiro (2005, pp. 27-34) considera que:

[...] o envelhecimento é um processo contínuo de transformação do humano como ser único em seu tempo vivido; [ ...] envelhecer é sinônimo de viver; [ ...] viver é conhecer; [ ...] o viver humano constitui-se possibilidade de construção, desconstrução e reconstrução de configurações totalmente diferenciadas a cada instante em suas experiências formando o seu sentido histórico através do espaço relacional com o mundo e com os outros; [...] o velho precisa continuar sua caminhada permeado pelo amor, porque sua dinâmica biológica depende disso.

Nessa concepção, em todo o processo de ensino-aprendizagem as histórias são construídas permeadas pelas histórias dos outros e por meio da seleção necessária dos conteúdos do aprendizado que possam ampliar as perspectivas de conhecimento. Na velhice, todo o conhecimento adquirido servirá de base para o organismo se adaptar adequadamente a cada circunstância que o envolve.

Em linha com Monteiro \& Debert (2004, pp. 100-101) reforça que “o velho é depositório de uma experiência e de um saber único e exclusivo dado pelos anos vividos. A memória é um bem valioso que, assim como a história, deve ser transmitida às gerações mais jovens". Nesse mesmo alinhamento, Cachioni $\&$ Neri (2004) relembram a capacidade que o indivíduo idoso tem de selecionar e se concentrar naqueles domínios que são altamente prioritários. Tais domínios, por sua vez, envolvem a convergência de demandas ambientais e da capacidade biológica das habilidades e das motivações individuais. Sob tais perpectivas, como pode a velhice ficar fora da imbricada relação entre o indivíduo, a carreira e o mercado de trabalho?

Faz-se oportuno trazer aqui o conceito de velhice produtiva, expressão da literatura gerontológica com referência à possibilidade de envelhecer bem. Assim, tomando-se novamente por base Cachioni \& Neri (2004), essas autoras enfatizam os significados associados a várias áreas da atividade humana contidos no conceito de velhice produtiva. Elas dizem, ainda, que esse conceito excede os limites da atividade economicamente produtiva e do trabalho. Entretanto, de acordo com Beres (2002), quando uma pessoa aposentada retira-se do trabalho deixa de existir enquanto ser social, uma vez que a sociedade não tarda em qualificá-la como velha, ao tomar conhecimento de sua aposentadoria. Magalhães, Krieger, et a/ (2004, p. 58) relebram que "[ ...] a interrupção de atividades desenvolvidas ao longo de uma vida no cenário do mundo do trabalho, e a consequente perda dos vínculos sociais ali estabelecidos, pode trazer danos severos à qualidade de vida das pessoas". Esse isolamento social, determinado pelo meio social, leva ao envelhecimento, na visão desses autores.

De acordo com Dutra (2011), a fase de maturidade de uma pessoa entre 45 e 64 anos é apontada como a fase de permanência. É nessa fase que as pessoas vivem muitos processos de mudança em suas carreiras devido à turbulência no ambiente profissional. São notados, também como consequência de mudanças na estrutura familiar, novos papeis para a mulher e para o casal em suas relações.

Para esse autor, a fase da velhice caracterizada após os 64 anos é vista como a fase de declínio das capacidades físicas e mentais, levando as pessoas, de maneira geral, a esconder-se e retirar-se 
gradativamente de suas atividades habituais. Devido a essas mudanças de fase, a relação das pessoas com suas carreiras sofre alterações no curso da vida. Beres (2002, p. 92) relembra que "[ ...] é a partir do século XIX, com o advento da Era Industrial, que a substituição dos funcionários mais antigos por outros com formação técnica, na busca desenfreada da constante atualização que começa a configurar-se a idade social da velhice determinada pela sociedade". Pelo exposto depreende-se que há momentos na vida das pessoas em que, em função da idade, relação profissional e situação familiar, sofrem pressões que podem influenciar nas decisões profissionais.

Outro fato importante é que a expectativa de vida das pessoas aumentou significativamente nos últimos anos, graças aos avanços da medicina. Nas organizações há setores compostos por pessoas de várias faixas etárias, profissionais sêniores compartilhando projetos com trainees. Magalhães, Krieger, et a/ (2004, p. 61) alertam que "o envelhecimento constitui uma ameaça para os apegados, que tentavam manter os padrões vitais da meia idade".

O profissional aposentado em uma carreira não necessariamente sai do mercado de trabalho. Ao vislumbrar uma oportunidade pode recomeçar em uma nova carreira. Todas essas mudanças no cenário organizacional convidam o indivíduo a uma reflexão sobre a gestão de sua carreira. Segundo Evans (1996), as carreiras estão se transformando em espiral e em ziguezague em vez de escadas, ou seja, com tais mudanças nesse cenário ao longo da vida profissional o indivíduo pode ter várias carreiras.

A literatura referenciada nesta fundamentação teórica apontou a aposentadoria como a maior transição da idade adulta, por assinalar, socialmente, a transição da meia-idade para a velhice. Alertou que a aposentadoria pode representar, para muitos indivíduos, a presença indiscutível de questões críticas da existência, como a proximidade com a morte, por exemplo. Apesar dessas considerações, a própria literatura mostra que a aposentadoria não implica necessidade de sair de cena, mas pode implicar início de nova carreira em outra área ou direção. E, sob tais perpectivas, a velhice não precisa estar fora da imbricada relação entre o indivíduo, a carreira e o mercado de trabalho.

\section{Aspectos Metodológicos da Pesquisa}

Na pesquisa de abordagem qualitativa, em geral, e do método do fenomenológico, em particular, o objetivo é explorar e desvendar conhecimentos por intermédio da experiência vivida do sujeito. No contexto da pesquisa qualitativa, privilegiam-se, neste artigo, as premissas de Mattos (2006) fora do paradigma das ciências naturais, de pesquisas que optaram pela linguagem natural aberta, em que se tem uma nova ordem de conhecimento, especialmente preciosa para a administração, contemplando aqui essa experiência dos sujeitos da pesquisa.

Ainda no que tange à abordagem de pesquisa qualitativa com respaldo em Richardson (1989) que trata do uso de percepções, compartilhamento dos significados e a dinâmica das interações grupais, por intermédio de seus significados para as pessoas e Chizzotti (2008, p. 58) que enfatiza: "os pesquisadores que optaram pela pesquisa qualitativa, ao se decidirem pela descoberta de novas vias investigativas, não pretenderam nem pretendem furtar-se ao rigor e à objetividade, mas reconhecem que a experiência humana não pode ser confinada aos métodos nomotéticos de analisá-la e descrevê-la".

Assim respaldado, este artigo utiliza-se da pesquisa qualitativa e toma como base empírica de observação indireta a peça "DonAna". Os critérios de escolha para sua utilização foram determinados pela incidência de trabalhos envolvendo a arte em educação e administração, a exemplo de: Wood Jr (2000); Duarte (2002); Vergara (2003); Vergara (2007); Almeida (2004); Brandão (2004); Costa (2004); Davel et al. (2004); Koudela \& Santana (2005); Carvalho (2007); Leite, N. R. P. \& Leite (2007); Davel et al. (2007); Ipiranga (2007); Taylor (2007); Cavassin (2008); Mattos (2009); Napolitano (2009); Leite, N. R P. \& Leite (2010); Leite, et al. (2010); Leite, N. R. P., Leite, et al. (2010).

Conforme Leite, et al. (2010), inserido na perspectiva do exame minucioso de comportamentos ou atividades, o estudo observacional, classificado como direto ou indireto, pode ser visto respectivamente, com relação à personagem da peça estudada. Para efeitos desta pesquisa e, ainda em consonância com esses autores, é adotada a noção de diferentes interpretações dos dados coletados da peça estudada, considerando-se que essas interpretações, de múltiplos intérpretes, podem ser analisadas e comparadas no tocante às diferentes construções de suas realidades, especificamente sobre a temática de carreira, mercado de trabalho e velhice. 
Nessa perspectiva metodológica e além da observação da peça, assistida 22 vezes pelas pesquisadoras, foram ainda utilizadas para coleta de dados primários, as seguintes fontes de evidência: entrevista em profundidade com o autor e ator da peça; questionário aberto e semiestruturado em uma survey de experiência com 107 discentes envolvidos no processo de ensino-aprendizagem com essa peça; um grupo focal com 11 discentes que também assistiram à peça e fizeram exercícios em sala de aula. A participação desses 118 discentes ocorreu em 2011, todos eles oriundos do curso de Administração de Recursos Humanos de uma universidade privada da cidade de São Paulo.

Desse total de discentes, 107 responderam, individualmente, nessa survey de experiência às questões: Qual a relação entre o teatro e a formação do profissional de RH? Que valores sustentam essa relação? Qual a relação entre carreira, mercado de trabalho e velhice? Que reflexões essa relação suscita? Qual a aprendizagem desses discentes em sala de aula, oriunda de sua ida ao teatro e de sua reflexão sobre o espetáculo? Qual a importância desse espetáculo nas concepções individuais desses discentes, acerca da forrmação em RH, carreira, mercado de trabalho e velhice? Posteriormente, 11 discentes estiveram envolvidos em grupo focal, discutindo essas mesmas questões. Contextualize-se que essas questões foram geradoras das categorias de análises dos dados obtidos.

A partir do objeto de estudo, objetivos, questão de pesquisa e arcabouço teórico é que foi construído esse roteiro de entrevista survey de experiência. De acordo com Cooper \& Schindler (2003, p. 33), o que se busca nesse delineamento de pesquisa são as "ideias em relação a questões ou aspectos importantes do assunto tratado e descobrir o que é importante dentro do campo de conhecimento das pessoas". Para os autores, uma survey está classificada como uma abordagem de comunicação, a qual envolve, além do questionamento em que o ponto forte é a versatilidade, o registro de respostas para análise.

Após a survey de experiência foi realizada uma reunião de grupo focal, o qual pode ser conceituado como um tipo de entrevista em profundidade, realizada em grupo, cujas reuniões têm características definidas quanto à proposta, ao tamanho, à composição e aos procedimentos, de acordo com Oliveira \& Freitas (2006). Tal conceituação encontra, parcialmente, respaldo em Morgan (1997), pelo qual o grupo focal é considerado uma técnica intermediária entre a observação participante e a entrevista aberta, sem que uma técnica substitua a outra, e se utiliza, explicitamente, da interação grupal a respeito de um tema, em um período limitado.

Nessa circunstância, a pluralidade das ideias é o que se busca, o que possibilita ao pesquisador aprofundar a compreensão das respostas obtidas. Powell \& Single (1996) e Gatti (2005) defendem que os participantes de um grupo focal necessitam ter alguma vivência com o tema a ser discutido, de modo que sua participação traga elementos ancorados em suas experiências cotidianas. Essas experiências permitem a captação de significados que, em outros meios, poderiam ser difíceis de manifestar, conforme afiançam esses autores. Kind (2004) assume o grupo focal como uma técnica de coleta de dados, justificada pelo fato de acreditar na necessidade de uma utilização conscienciosa. Nesta pesquisa ele foi utilizado para coleta de dados que pudessem ser confrontados com a etapa de coleta individual por meio da survey de experiência.

As reuniões de discussão poderão ser feitas por um único pesquisador, considerado como o moderador/facilitador do processo, promovendo a participação de todos ou por uma equipe composta pelo pesquisador, um ou mais moderadores e um assistente de pesquisa, cada um com suas funções e atribulações definidas antecipadamente, de acordo com Vergara (2005). Nesta pesquisa a reunião do grupo focal foi conduzida por um único pesquisador.

Os dados levantados por meio da entrevista em profundidade, das entrevistas survey de experiência e do grupo focal foram analisados por intermédio da análise de conteúdo, segundo Bardin (2010), a qual considera que tal análise se apresenta como um conjunto de técnicas de análises das comunicações emitidas nos processos de coleta de dados. Essa análise faz uso de procedimentos sistemáticos e objetivos de descrição do conteúdo das mensagens. Essas técnicas que formam o conjunto consistem em análise categorial, que leva em consideração a totalidade da mensagem e a classifica de acordo com a presença ou a ausência dos elementos significativos e constitutivos dessa mensagem.

Esses elementos são chamados de unidades de codificação, constituídas de palavras ou frases que tragam significados pertinentes ao conteúdo. Cada uma das categorias compôs a construção da TDF (Tabela de Distribuição de Frequências). As figuras (1-6) foram elaboradas pelo Software Exce/. 


\section{O Contexto do Estudo}

Resultante de um texto de extraordinária beleza poética aliada ao indiscutível talento do autor e ator Ronaldo Ciambroni, que o escreveu quando tinha somente dezesseis anos de idade, "DonAna" conta com seu domínio absoluto há trinta e sete anos, encenada em teatros, espaços culturais, escolas, clubes, especiais para TV. A estrea desse texto data de 1974, no teatro Gauairá, Paraná. Não obstante Ciambroni viver em São Paulo, essa peça ultrapassou os muros de vários estados brasileiros e de diversas instituições. Foi mais além, vencendo as barreiras geográficas, culturais e da própria língua, encenada fora do Brasil, sempre na língua original e entendida pelos povos de outras línguas.

Ronaldo Ciambroni é um ator premiado por seus trabalhos em teatro e entre os prêmios, figuram dois "Molierè" (74 e 88) APCA - SNT e Mambembe. Esse espetáculo mostrou-se, por todos esses anos, capaz de continuar atual, em uma época na qual os valores, as idéias e tendências, se alternam de forma tão rápida. "DonAna" recebeu, em 1995 o prêmio de melhor espetáculo estrangeiro no festival de Havana - Cuba. Foi considerado pela crítica européia, um dos dez melhores espetáculos estrangeiros.

A Prefeitura de Mongaguá - São Paulo homenageou o ator, inaugurando no Centro Cultural Raul Cortez, o Teatro Municipal Ronaldo Ciambroni. "DonAna" ultrapassou, ainda, a barreira da quarta parede do teatro e participou de importantes eventos como: leitura de uma carta no Congresso Nacional defendendo os direitos do idoso brasileiro; participação no filme de José de Anchieta, "Ponto Final"; representação do Brasil em Cannes; participação inspiradora do programa de humor "A Praça é Nossa" em uma das emissoras brasileiras de televisão.

Em linguagem fluente, cômica e simples, "DonAna" fala da vida de uma anciã octogenária na sociedade contemporânea. Com poder de suscitar reflexões, para todos que a assistem, essas reflexões ficam por conta de cada indivíduo. Nesta pesquisa, elas giram em torno da carreira, do mercado de trabalho e da velhice.

Os trechos do texto que as respaldam são: “Uma ocasião eu queria ser secretária de uma grande firma [ ...] Alberto não deixou. [ ...] E todo mundo falava: Ana, você tem queda pra dança e pro teatro [ ...] Hoje eu poderia estar fazendo televisão [ ...] Professora eu não fui porque eu não quis ser! [ ...] Ana... sou eu... eu sou a bailarina... Ei bailarina, cadê você? [ ...] Eu estou aqui Ana... como sempre estive! Na gaveta... no baú... dentro do armário... na tua vontade... só na tua vontade... dentro da vontade! [...] Você não é bailarina Ana. Você é uma velha que nunca dançou! [ ...] Alberto que vivia dizendo: Ana, não se meta nesse negócio de dança... nesse negócio de teatro! [ ...]".

Vale lembrar que tais trechos, por sua vez, são respaldados por Beres (2002) ao falar da idade social da velhice determinada pela sociedade, configurando-se a importância da reflexão, desde cedo, em torno da carreira, do mercado de trabalho e da velhice, passando pelos momentos na vida das pessoas, em que aparecem as pressões, quer em função da situação familiar, da relação profissional, ou da idade. É importante salientar que as decisões profissionais podem ser influenciadas por essas pressões. Autodidata, em sua própria trajetória de carreira no teatro, o autor / ator dessa peça declarou que precisou vencer os obstáculos iniciais da própria família que não queria que ele vivesse da carreira de ator.

\section{Apresentação, Análise e Discussão dos Dados}

Contextualize-se que a discussão dos dados desta pesquisa está respaldada metodologicamente em Richardson (1989), quando abordados as percepções dos respondentes, o compartilhamento dos significados das unidades de análise e a dinâmica das interações do grupo focal. Em Bardin (2010), quando são consubstanciadas a análise categorial e a classificação de acordo com a presença ou a ausência dos elementos significativos e constitutivos das mensagens dos respondentes.

Iniciando-se a apresentação, análise e discussão dos dados pela entrevista em profundidade com o autor/ator da peça em estudo, ele afirma: "DonAna é um presente divino, recebido em 1974, logo no início da minha carreira e, ao longo dessa trajetória, vem me ajudando a produzir outras peças. Ela está em cartaz todo esse tempo porque eu nunca parei de fazer o que ela me inspira". A evolução do texto "DonAna" se dá com a passagem do tempo de vida do autor que o escreveu aos dezesseis anos, antes, portanto, de vivenciar a maturidade e, a cada década em que a encena pode sentir mais profundamente o que imaginava que a senhora que o inspirou pudesse sentir. 
Como visto na fundamentação teórica, o tempo é o responsável por formar e nutrir a experiência de toda uma vida, modificar as perspectivas e direções a serem tomadas na trajetória de vida e carreira, usufruir escolhas, compreender perplexidades, ansiedades, fascinações, deslumbramentos, desconhecimentos, estranhezas e incertezas, além de possibilitar contribuições para orientações dos mais jovens. Relembre-se, nesse ponto Monteiro (2005), ao falar dos processos de construção, desconstrução e reconstrução de configurações totalmente diferenciadas a cada instante em que as experiências são vivenciadas, formando o seu sentido histórico por intermédio do espaço relacional com o mundo e com os outros.

O entrevistado fez alusão à dificuldade do mercado de trabalho no teatro para o iniciante e para o ator idoso, nesse caso, por barreiras como preconceito, por exemplo. Para Dutra (2011), a fase da velhice pode implicar declínio das capacidades físicas e mentais, levando as pessoas, de maneira geral, a esconder-se e retirar-se gradativamente de suas atividades habituais, o que pode vir a repercutir na relação com suas carreiras e, em consequência sofrer alterações no curso da vida. Hoje o autor / ator entrevistado considera que, por ter facilidade de escrever os textos, pode colocar no palco as coisas em que sempre acreditou, levando ao público, além do entretenimento, reflexões. Declara-se feliz com a carreira, sobretudo por poder estar no mercado de trabalho fazendo o que sabe e dando o melhor de si mesmo, não obstante as limitações da idade já se fazerem presentes.

Os depoimentos do entrevistado estão em linha com Monteiro (2005) e Debert (2004) no que se refere à experiência e a um saber único e exclusivo oriundos dos anos vividos. Do mesmo modo, à memória e à história a ser transmitida às gerações mais jovens. Tais depoimentos ainda encontram respaldo em Cachioni \& Neri (2004) quando se referem à seleção e concentração em domínios prioritários e convergentes com as demandas ambientais e à capacidade biológica das habilidades e das motivações individuais.

Prosseguindo-se com a apresentação, análise e discussão dos dados pela survey de experiência e, ainda tomando-se por base os depoimentos do entrevistado, pode-se afirmar que os dados obtidos nessa fonte de evidência também estão alinhados com Debert (2004) no que tange à memória e à história a ser transmitida às gerações mais jovens, como pode ser verificado a seguir, em cada uma das seis categorias analisadas junto aos 107 discentes que compuseram o grupo de respondentes.

A Tabela 1 apresenta as seis categorias de análise, bem como as unidades de análise constituídas de palavras/frases que trazem significados pertinentes ao conteúdo das mensagens das respostas individuais desses 107 discentes. Do mesmo modo, mostra as unidades de codificação, em que aparecem as frequências das presenças e ausências dos fragmentos dessas mensagens.

Tabela 1 - Base para a Análise de Conteúdo

\begin{tabular}{|c|c|c|c|}
\hline \multirow{2}{*}{$\begin{array}{l}\text { Categorias de } \\
\text { Análise } \\
\text { (questões) }\end{array}$} & \multirow{2}{*}{$\begin{array}{l}\text { Unidades de Análise } \\
\text { (palavras ou frases) }\end{array}$} & \multicolumn{2}{|c|}{$\begin{array}{l}\text { Unidades de Codificação } \\
\text { Freq. Simples / } \\
\text { Freq. Relativa }\end{array}$} \\
\hline & & $\begin{array}{c}\text { Presença/ } \\
\text { Ausência \% }\end{array}$ & $\begin{array}{c}\text { Presença/ } \\
\text { Ausência \% }\end{array}$ \\
\hline $\begin{array}{l}\text { 1. Relação entre } \\
\text { o teatro e a } \\
\text { formação do } \\
\text { profissional de } \\
\text { RH }\end{array}$ & $\begin{array}{l}\text { Aprendizagem/Conhecimento/Cultura/Desenvolvimento } \\
\text { Concentração/Criatividade/Harmonia/Organização/Sincronia } \\
\text { Confiança } \\
\text { Comunicação/Empatia/Flexibilidade } \\
\text { Crescimento Profissional (capacidade) } \\
\text { Desempenho } \\
\text { Desinibição/Desenvolturaz } \\
\text { Doação } \\
\text { Emoção/Motivação/Reflexão } \\
\text { Oportunidade } \\
\text { Postura } \\
\text { Relacionamento interpessoal }\end{array}$ & $\begin{array}{l}40 / 17,09 \\
27 / 11,54 \\
4 / 1,71 \\
75 / 32,05 \\
5 / 2,14 \\
3 / 1,28 \\
19 / 8,12 \\
5 / 2,14 \\
16 / 6,84 \\
9 / 3,85 \\
4 / 1,71 \\
27 / 11,54\end{array}$ & $\begin{array}{l}194 / 82,91 \\
207 / 88,46 \\
230 / 98,29 \\
159 / 67,95 \\
229 / 97,86 \\
231 / 98,72 \\
215 / 91,88 \\
229 / 97,86 \\
218 / 93,16 \\
225 / 96,15 \\
230 / 98,29 \\
207 / 88,46\end{array}$ \\
\hline
\end{tabular}


Carreira, mercado de trabalho e as lições de "DonAna" no processo de ensino-aprendizagem e pesquisa em administração

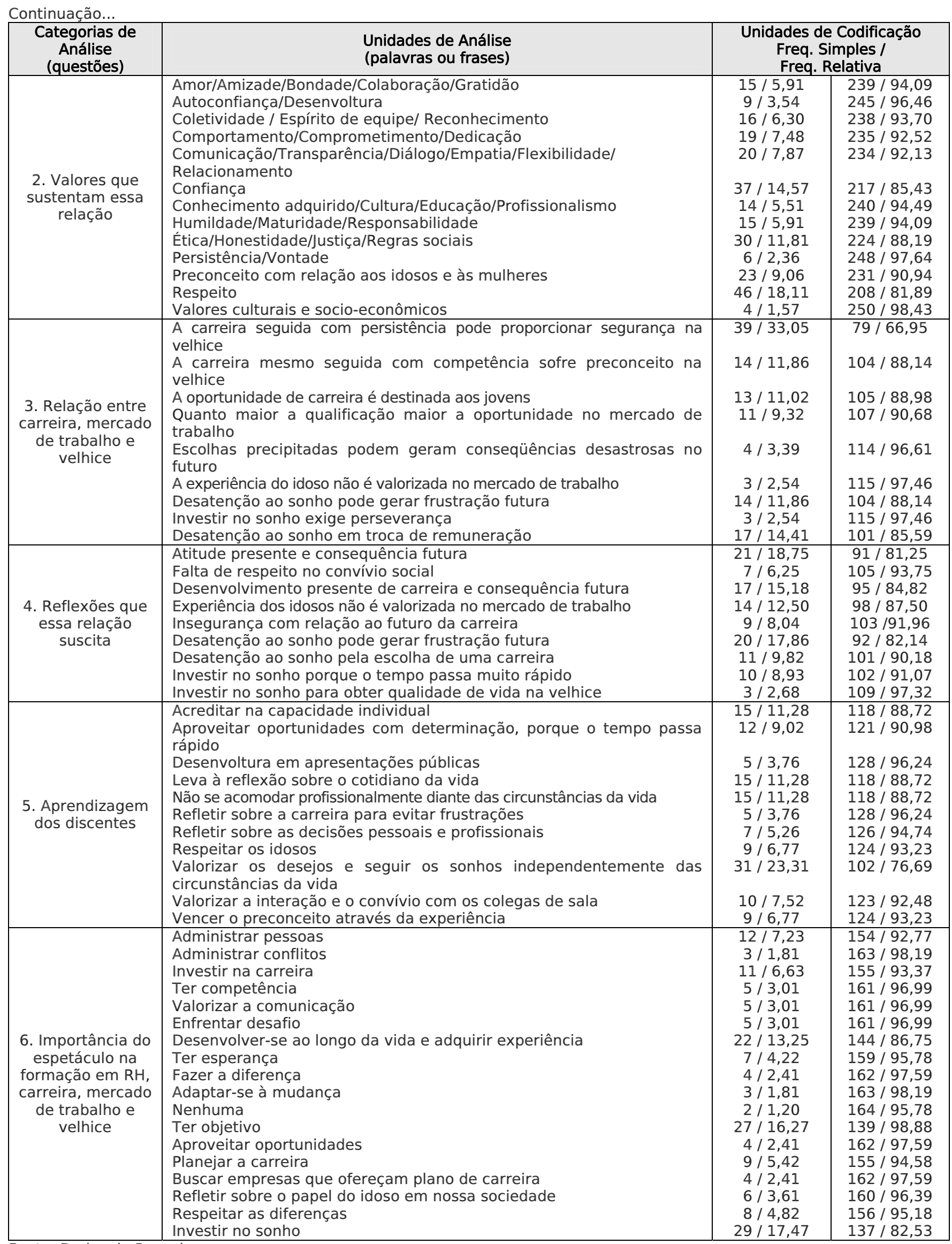

Fonte: Dados da Pesquisa 
A base de dados da Tabela 1 foi obtida por meio de pesquisa com esses 107 discentes do curso de Administração de Recursos Humanos. As análises realizadas tiveram como base os cálculos da moda. No que se refere à variável qualitativa, foi realizada a análise das seis categorias, oriundas das seis questões utilizadas na survey de experiência, representadas pelas figuras de 1 a 6 .

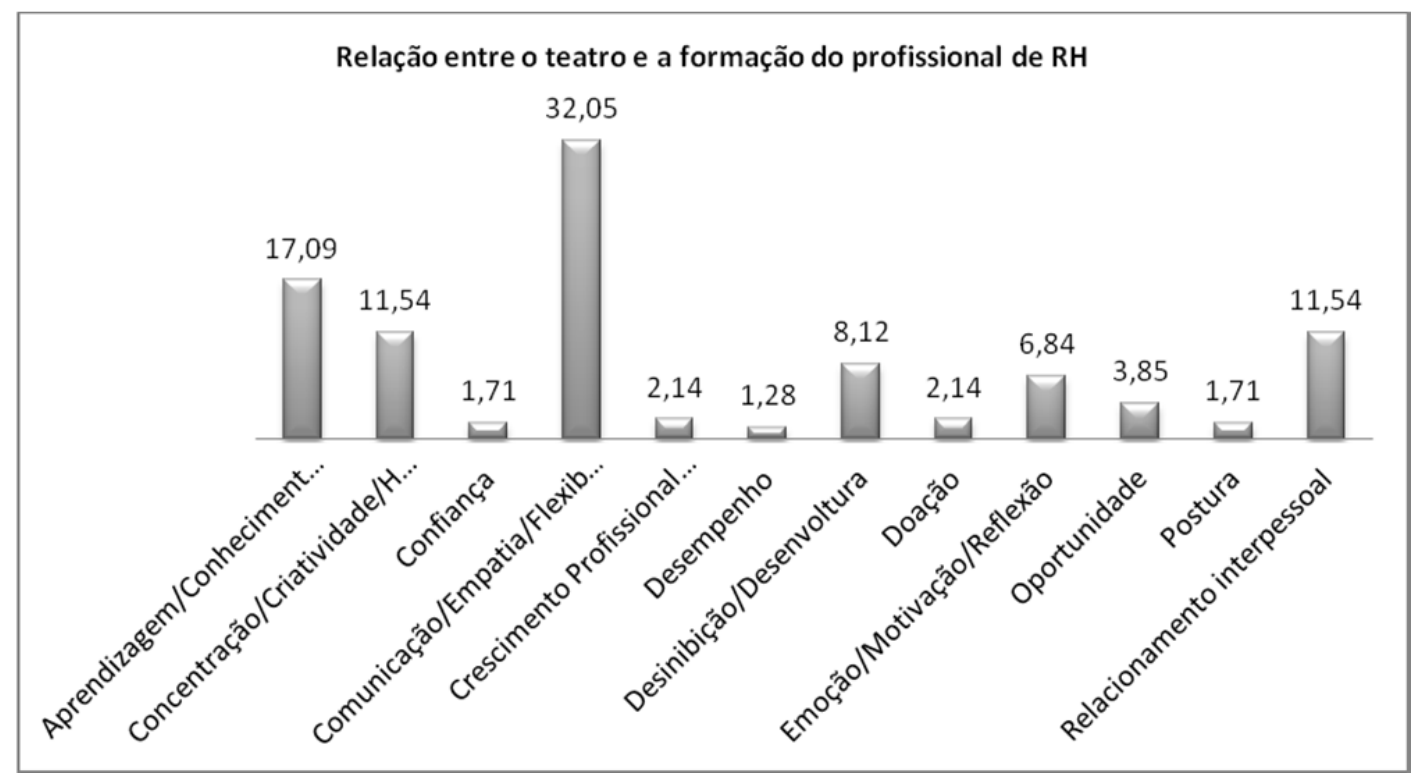

Figura 1 - Relação entre o Teatro e a Formação do Profissional de RH

Fonte: Dados da Pesquisa

A Figura 1 apresenta a categoria 1, 'Relação entre o teatro e a formação do profissional de RH'. Nessa categoria os discentes que fizeram parte da survey de experiência falaram de emoção, motivação, reflexão e oportunidades de aprendizagem e ampliação do conhecimento com a peça estudada, o que remete à lembrança do que foi dito por Costa (2004) acerca da importância do teatro como instrumento da pedagogia jesuítica nos primórdios da educação brasileira.

Para esses discentes, o incremento da concentração, da criatividade, da harmonia, da organização das ideias, da sincronia e do relacionamento interpessoal com os colegas foram atribuídos ao uso do teatro como instrumento pedagógico.

A Figura 1 mostra, também nessa categoria, a importância de variáveis como: comunicação, empatia e flexibilidade ao relacionar o teatro e a formação específica do profissional de RH.

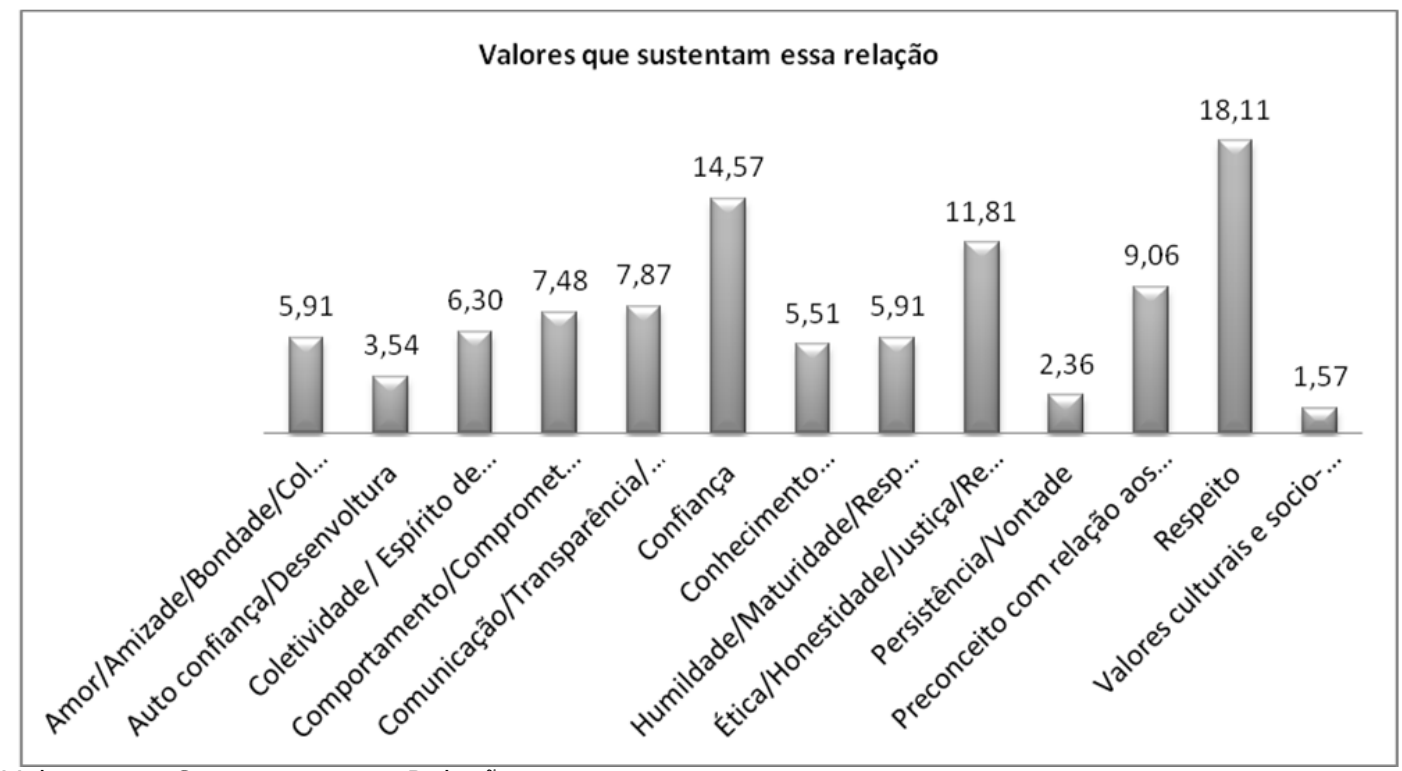

Figura 2 - Valores que Sustentam essa Relação

Fonte: Dados da Pesquisa 
Na Figura 2 pode ser vista a categoria 2, 'Valores que sustentam a relação entre o teatro e a formação do profissional de $\mathrm{RH}^{\prime}$, na qual os discentes elencaram como prioritários: respeito, confiança, ética, honestidade, justiça, regras sociais.

Na sustentação dessa relação os discentes respondentes ressaltam a importância do conhecimento adquirido, o incremento da cultura por intermédio do teatro, da educação diferenciada, e do profissionalismo com que podem encarar suas reflexões sobre o planejamento de suas carreiras, o que, sob a ótica de Magalhães \& Gomes (2005), se refere à disposição para fazer algo com respeito à escolha de uma ocupação, relacionando-a ao efetivo desenvolvimento dessas carreiras.

Ainda com relação à Figura 2, ao trazerem o preconceito com relação aos idosos e às mulheres, esses discentes se alinham a Beres (2002) e Dutra (2011) quanto aos processos de reflexões acerca de possibilidades de mudança em suas carreiras, o trato dado pela sociedade e a possibilidade de turbulência no ambiente profissional.

A Figura 3 representa a categoria 3, 'Relação entre carreira, mercado de trabalho e velhice'. Nela, os discentes acreditam que: a carreira seguida com persistência pode proporcionar segurança na velhice; a desatenção ao sonho pode ocorrer em troca de remuneração; mesmo planejada e seguida com competência, a carreira pode sofrer preconceito na velhice; a desatenção ao sonho pode gerar frustração futura; a oportunidade de carreira é destinada aos jovens; quanto maior a qualificação maior a oportunidade no mercado de trabalho.

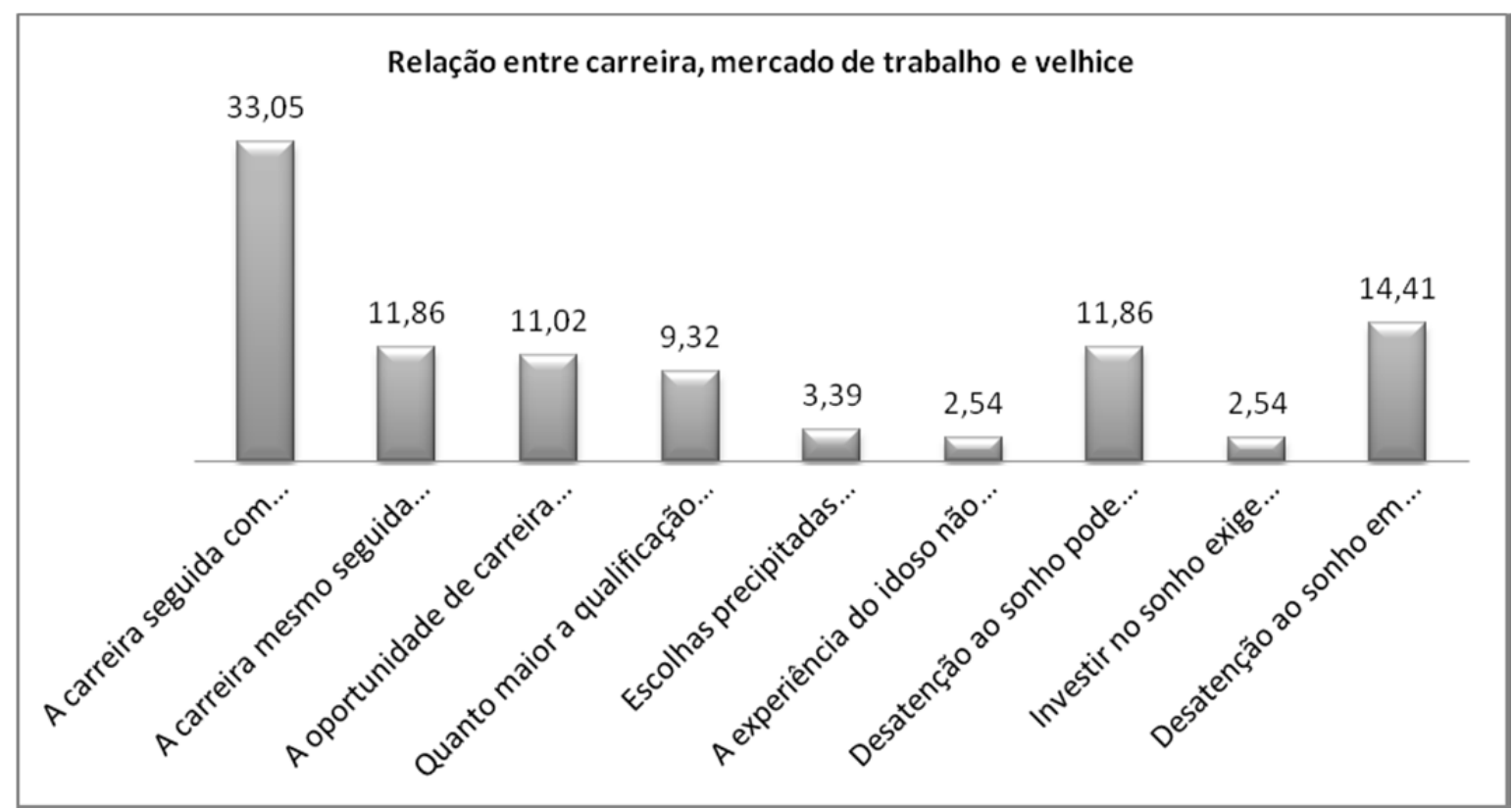

Figura 3 - Relação entre Carreira, Mercado de Trabalho e Velhice Fonte: Dados da Pesquisa

O elenco de crenças dos discentes, nessa categoria, mostra um dos recursos com os quais o indivíduo pode contar - o projeto profissional - e sua subdivisão, conforme sugerido por Dutra (2002), em etapas: autoconhecimento; conhecimento do mercado; estabelecimento dos objetivos de carreira; estabelecimento das estratégias de carreira; definição de um plano de ação; acompanhamento desse plano de ação.

A Figura 4 é a responsável por representar a categoria 4, 'Reflexões suscitadas pela relação entre carreira, mercado de trabalho e velhice'. Em suas reflexões, os discentes se reportam, primordialmente a: atitude presente diante da carreira e consequência futura; desatenção ao sonho podendo gerar frustração futura; desenvolvimento presente da carreira pode ser responsável pela consequência futura; experiência dos idosos não é valorizada no mercado de trabalho; comportamento de desatenção ao sonho na escolha de uma carreira; necessidade de investir no sonho, porque o tempo passa muito rápido.

Tais reflexões, além de reforçarem o que é dito na categoria 3, relembram Magalhães \& Gomes (2005) ao fazerem alusão: às preferências vocacionais e suas implicações no modo como os indivíduos conduzem suas carreiras, contibuem socialmente e deixam o seu legado para a posteridade; aos indivíduos, quando se desenvolvem na carreira e ampliam a complexidade do seu papel nas organizações. 


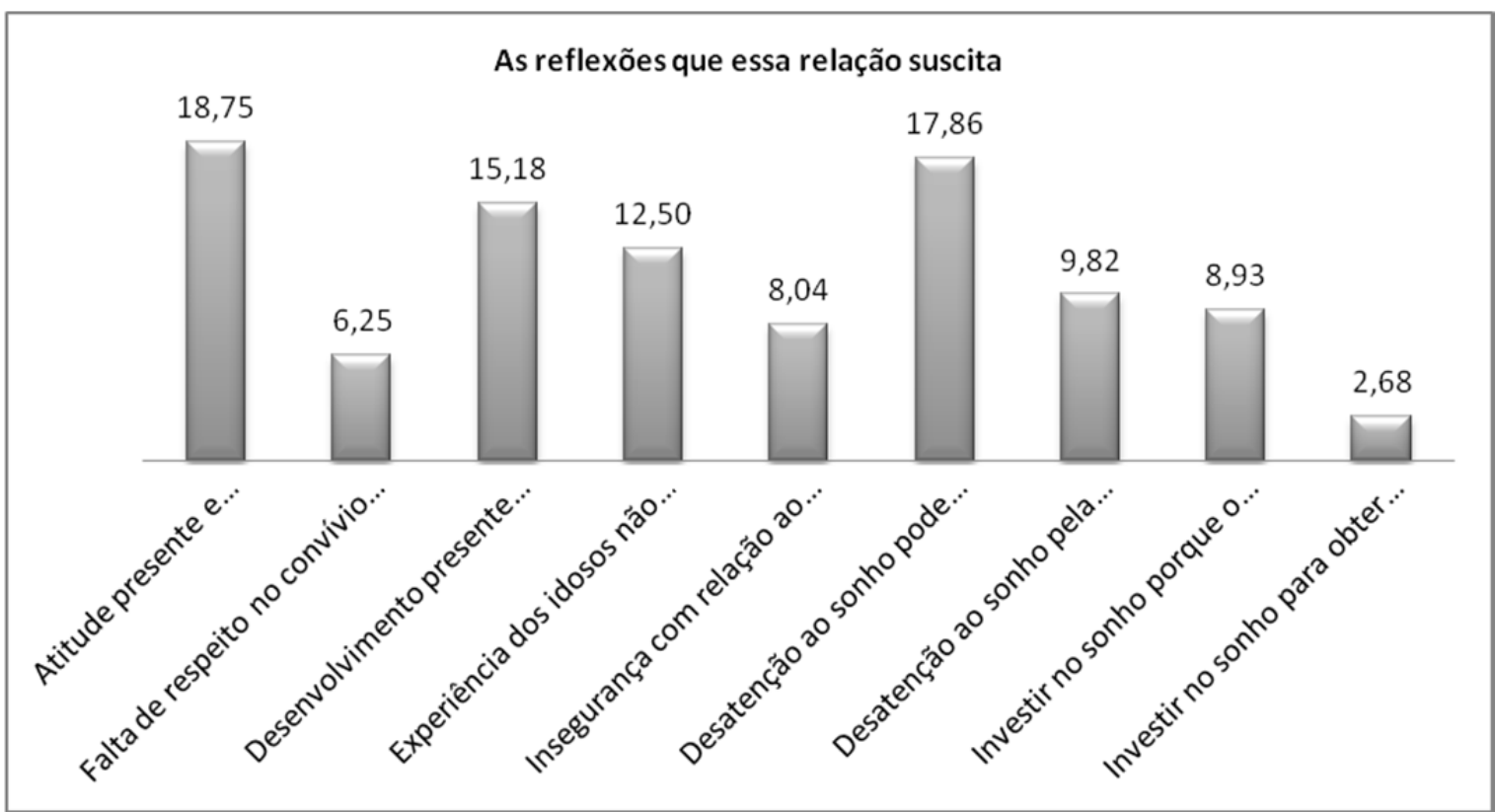

Figura 4 - As Reflexões que essa Relação Suscita

Fonte: Dados da Pesquisa

A Figura 5 trata da categoria 5, 'Aprendizagem dos discentes' os pontos de maior incidência de resposta foram: valorizar os desejos e seguir os sonhos, independentemente das circunstâncias da vida; acreditar na capacidade individual; não se acomodar profissionalmente diante das circunstâncias da vida; passar à reflexão sobre o cotidiano da vida; aproveitar oportunidades com determinação, porque o tempo passa rápido.

Chama a atenção o fato de a figura mostrar que, o aprendizado mais significativo para esses discentes inclui a valorização dos desejos e a busca dos sonhos durante as etapas da vida. Tal fato encontra-se plenamente alinhado ao texto final da peça, em que o autor fala dos sonhos com pesar: "a chuva veio lavar os meus pecados! Os pecados que eu pensei ter cometido e que se resumiram num só... eu ter acreditado nos sonhos que nunca existiram...".

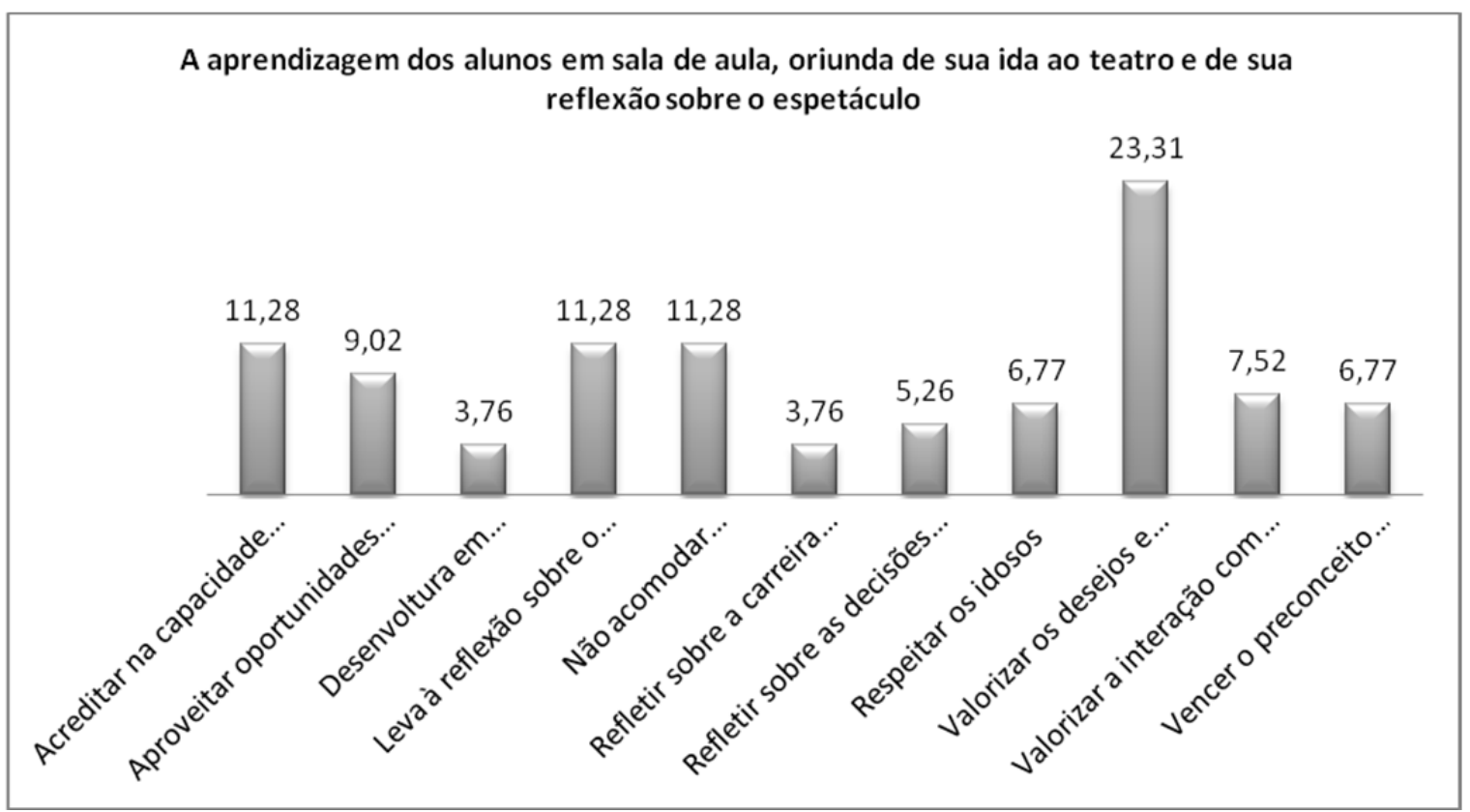

Figura 5 - A Aprendizagem dos Alunos em Sala de Aula Fonte: Dados da Pesquisa 
Nessa categoria, o alinhamento do aprendizado dos discentes se dá com Koudela \& Santana (2005), quando afirmam que os pressupostos epistemológicos de uma metodologia do ensino necessitam proporcionar o conhecimento da estrutura teórico-prática dos procedimentos que levam à aprendizagem, não somente na esfera do teatro, como em qualquer outra área do conhecimento. Os efeitos desse alinhamento se fazem presentes também na categoria seguinte.

A Figura 6, por fim, representa a categoria 6, 'Importância do espetáculo na formação em RH, carreira, mercado de trabalho e velhice'. Os discentes trazem como importância principal a ação de investir no sonho. Ter objetivo é o que se segue. Desenvolver-se ao longo da vida e adquirir experiência, aproveitar oportunidades, planejar a carreira, refletir sobre o papel do idoso na sociedade e respeitar as diferenças são contextos associados ao alinhamento percebido na categoria 5 .

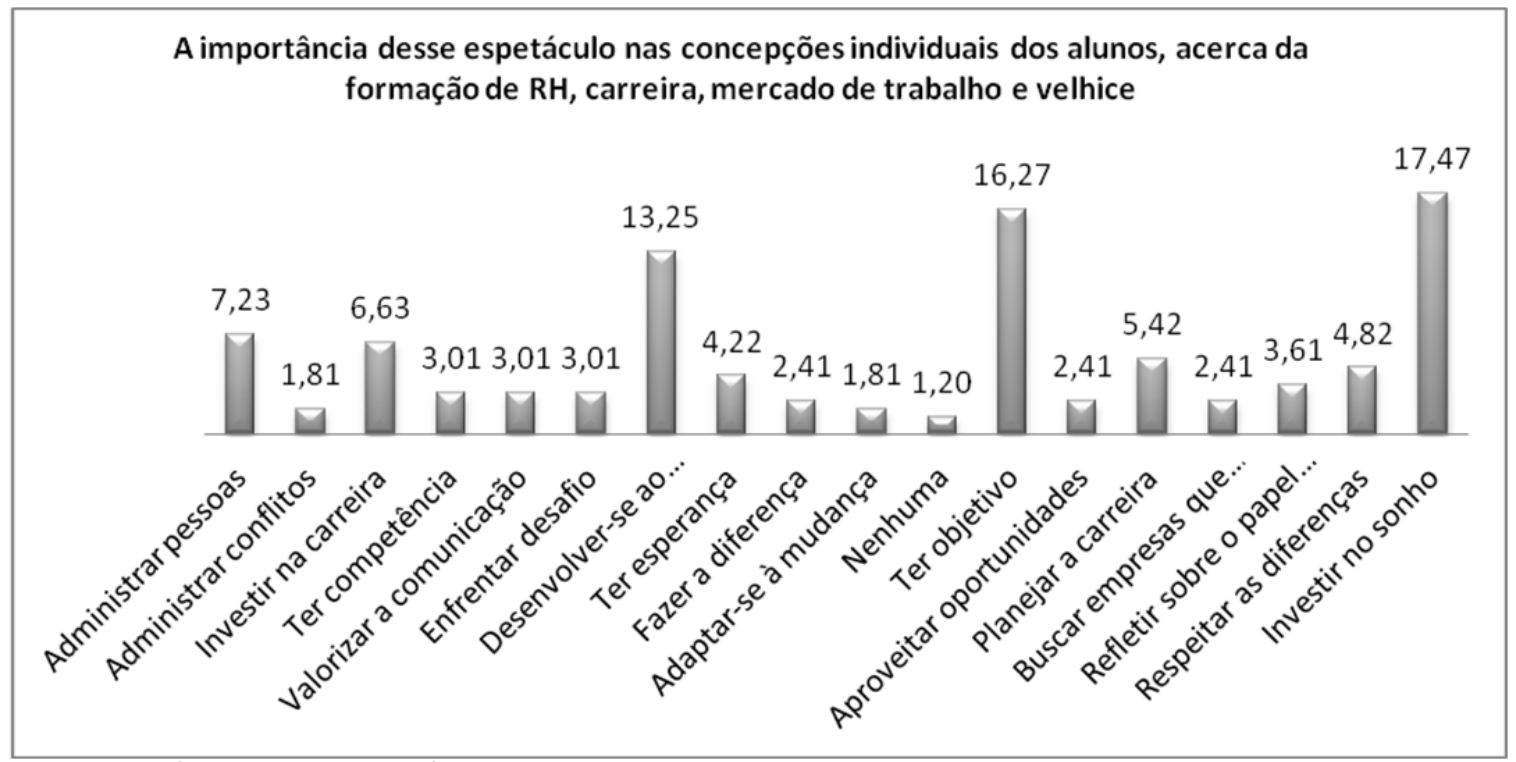

Figura 6 - A Importância desse Espetáculo nas Concepções Individuais dos Alunos Fonte: Dados da Pesquisa

As respostas obtidas na categoria 6 encontram-se respaldadas em London \& Stumph (1982), quando afirmam a clareza dos papeis e responsabilidades do indivíduo e mostram que, nessa perspectiva, a carreira engloba o entendimento e a avaliação de experiências profissionais desse indivíduo, a sequência de posições ocupadas no trabalho ao longo de sua vida, os estágios e transições que refletem necessidades, motivos e aspirações, bem como expectativas e restrições da família, da organização e da sociedade.

Dando continuidade à apresentação, análise e discussão dos dados pela via do grupo focal, a Tabela 2, além de apresentar as mesmas categorias de análise da tabela 1, traz as unidades de análise - constituídas de palavras/frases que contêm significados pertinentes ao conteúdo dessas mensagens. Mostra a contagem das unidades de análise (palavras ou frases), presentes ou ausentes nos fragmentos de mensagens trazidas pelos 11 integrantes do grupo focal, sem repetição na fala de um mesmo integrante.

Tabela 2 - Base para a Análise de Conteúdo

\begin{tabular}{|c|c|c|c|}
\hline \multirow{2}{*}{$\begin{array}{l}\text { Categorias de Análise } \\
\text { (questões) }\end{array}$} & \multirow{2}{*}{$\begin{array}{l}\text { Unidades de Análise } \\
\text { (palavras ou frases) }\end{array}$} & \multicolumn{2}{|c|}{$\begin{array}{c}\text { Unidades de Codificação } \\
\text { Contagem }\end{array}$} \\
\hline & & Presença & Ausência \\
\hline \multirow{2}{*}{$\begin{array}{l}\text { 1. Relação entre o } \\
\text { teatro e a formação } \\
\text { do profissional de RH }\end{array}$} & $\begin{array}{l}\text { O teatro ajuda a desenvolver habilidades; Aprendizagem sobre a } \\
\text { importância da comunicação, dicção e relacionamento interpessoal; } \\
\text { Ajuda profissional, no desenvolvimento do trabalho em equipe. }\end{array}$ & 7 & 4 \\
\hline & $\begin{array}{l}\text { O teatro é um veículo de comunicação; Amplia as relações e esclarece } \\
\text { conflitos e comportamentos; Provoca reflexão natural nas pessoas } \\
\text { sobre suas vidas; O profissional de RH pode utilizar esses conceitos } \\
\text { com a intenção de melhorar suas atividades profissionais. }\end{array}$ & 4 & 7 \\
\hline \multirow{2}{*}{$\begin{array}{l}\text { 2. Valores que } \\
\text { sustentam essa } \\
\text { relação }\end{array}$} & Respeito, confiança, amor & 11 & 0 \\
\hline & Lealdade & 4 & 7 \\
\hline
\end{tabular}


Iraides Gonçalves Amaral, Nildes R. Pitombo Leite, Eline Dias Moreira, Miriam Assunção Tazem Salgueiro

\begin{tabular}{|c|c|c|c|}
\hline $\begin{array}{l}\text { Categorias de Análise } \\
\text { (questões) }\end{array}$ & $\begin{array}{l}\begin{array}{l}\text { Unidades de Análise } \\
\text { (palavras ou frases) }\end{array} \\
\end{array}$ & \multicolumn{2}{|c|}{$\begin{array}{l}\text { Unidades de Codificação } \\
\text { Contagem }\end{array}$} \\
\hline \multirow[t]{2}{*}{$\begin{array}{l}\text { 3. Relação entre } \\
\text { carreira, mercado de } \\
\text { trabalho e velhice }\end{array}$} & $\begin{array}{l}\text { A principal relação entre carreira, mercado de trabalho e velhice é o } \\
\text { planejamento para a não acomodação, pois, muitas vezes não } \\
\text { fazemos e tampouco sugerimos ideias extraordinárias e criativas e } \\
\text { depois nos arrependemos por isso; Precisamos aproveitar o melhor da } \\
\text { vida e da carreira profissional e fazer a diferença na vida pessoal para } \\
\text { trilharmos o caminho do sucesso; A velhice e a carreira possuem } \\
\text { muita identificação, pois é importante aproveitar todos os momentos } \\
\text { da vida. }\end{array}$ & 7 & 4 \\
\hline & $\begin{array}{l}\text { Quando não aproveitamos o tempo para estudar e desenvolver } \\
\text { nossas ideias enquanto jovens, na velhice acabamos, muitas } \\
\text { vezes, por não ter novas oportunidades oferecidas pelo mercado } \\
\text { de trabalho. }\end{array}$ & 11 & 0 \\
\hline \multirow{2}{*}{$\begin{array}{l}\text { 4. Reflexões que essa } \\
\text { relação suscita }\end{array}$} & $\begin{array}{l}\text { Nos fez refletir sobre a importância da valorização da vida na } \\
\text { busca dos objetivos e sonhos levando em conta as oportunidades } \\
\text { que nos são oferecidas e não, simplesmente, realizando a vontade } \\
\text { dos outros para manter aparências. }\end{array}$ & 7 & 4 \\
\hline & $\begin{array}{l}\text { O espetáculo nos leva a refletir sobre a questão do respeito aos } \\
\text { mais velhos e a importância do nosso preparo para o futuro } \\
\text { próximo, de forma a continuar os estudos e buscar melhores } \\
\text { oportunidades ainda quando se é jovem. }\end{array}$ & 4 & 7 \\
\hline \multirow{2}{*}{$\begin{array}{l}\text { 5. Aprendizagem dos } \\
\text { discentes }\end{array}$} & $\begin{array}{l}\text { O teatro mostrou a convivência entre grupos de discentes; Trouxe } \\
\text { ideias para nossas apresentações e elaboração de trabalhos na } \\
\text { universidade. O teatro nos convida a ser mais comunicativos e } \\
\text { desinibidos. }\end{array}$ & 7 & 4 \\
\hline & $\begin{array}{l}\text { O convívio com os outros colegas foi muito importante para todos; } \\
\text { O espetáculo apresentou a realidade do envelhecimento e o } \\
\text { desrespeito ao idoso em nossa sociedade. }\end{array}$ & 4 & 7 \\
\hline \multirow{2}{*}{$\begin{array}{l}\text { 6. Importância do } \\
\text { espetáculo na } \\
\text { forrmação em RH, } \\
\text { carreira, mercado de } \\
\text { trabalho e velhice }\end{array}$} & $\begin{array}{l}\text { Temos que nos preparar, o quanto antes, para nossa formação } \\
\text { profissional, pois, o mercado de trabalho está muito competitivo; O } \\
\text { RH nos mostra a visão da organização em que os colaboradores } \\
\text { são os personagens do espetáculo. }\end{array}$ & 7 & 4 \\
\hline & $\begin{array}{l}\text { Esse espetáculo nos transmite informação e conhecimento sobre a } \\
\text { importância de se buscar um plano de carreira desde a juventude, } \\
\text { pois, nos dias de hoje, pessoas com idade mais avançada estão } \\
\text { sendo excluídas do mercado de trabalho. }\end{array}$ & 4 & 7 \\
\hline $\begin{array}{c}\text { 7. Você levou } \\
\text { acompanhante ao } \\
\text { teatro? } \\
\text { Se sim, qual a opinião } \\
\text { dele sobre a ida dos } \\
\text { alunos ao teatro? }\end{array}$ & $\begin{array}{l}\text { Muitos alunos e acompanhantes tiveram a oportunidade de } \\
\text { conhecer o teatro pela primeira vez. Dessa maneira tiveram } \\
\text { oportunidade de agregar conhecimentos e obter mais estímulos } \\
\text { para buscá-lo através da arte. }\end{array}$ & 7 & 4 \\
\hline
\end{tabular}

Fonte: Dados da Pesquisa

Além das seis categorias trabalhadas anteriormente, vê-se que a Tabela 2 apresenta uma questão a mais. É que, nesse ponto da apresentação, análise e discussão dos dados, faz-se relevante relembrar que os respondentes da survey de experiência deram depoimento de que muitos deles tiveram acesso ao teatro pela primeira vez. Do mesmo modo, essa questão reapareceu entre os integrantes do grupo focal, que ainda fizeram alusão ao fato de levarem consigo familiares e agregados, daí o acréscimo da questão 7.

Observe-se, na categoria 1, o grupo focal reforçando que o teatro ajuda a desenvolver habilidades e traz aprendizagens, o que condiz com a questão trazida por Costa (2004), ao preconizar a arte e a ludicidade como elementos catalizadores dos processos de ensino- aprendizagem.

Note-se, na categoria 2, que os valores respeito, confiança e amor são considerados os que sustentam a relação entre o teatro e a formação do profissional de $\mathrm{RH}$, o que também pôde ser visto no modo como os discentes e docentes interagiram ao longo das atividades.

Saliente-se, na categoria 3 que, em resposta sobre a relação entre carreira, mercado de trabalho e velhice, a idéia de estudar e aproveitar as oportunidades desde jovem para prever a velhice prevalece entre as demais, com a totalidade de presença na fala de todos os integrantes. Tal resultado se aproxima do que é dito por Magalhães \& Gomes (2005), quando mostram as mudanças que favorecem o cuidado com o planejamento de carreira e os profissionais imobilizados em suas posições de trabalho, incapazes ou desinteressados pela busca de novos desafios em suas carreiras.

Ressalte-se que, na categoria 4, as reflexões sobre a importância da valorização da vida na busca dos objetivos e sonhos, levando em conta as oportunidades de carreira e sem se pautar pela vontade de 
outrem, estão baseadas na realidade contemporânea. À época que em viveu “DonAna", anos 1930, optar pela carreira de esposa, mãe, dona de casa, era comum. O mercado de trabalho não era aberto às mulheres e, as poucas que trabalhavam ocupavam cargos de professora ou secretária, isso quando os maridos permitiam que elas tivessem uma carreira profissional.

Nessa categoria, as reflexões desses discentes encontram-se convergentes com London \& Stumph (1982), quando trazem a carreira, por um lado, movida pelos estágios e transições que refletem necessidades, motivos e aspirações dos indivíduos. Por outro lado, as expectativas e restrições da família, da organização e da sociedade também podem influenciar a carreira desses indivíduos. Para Evans (1996) administrar a carreira profissional, um casamento, carreira de pai, de mãe exige competência, tempo e consome muita energia, provoca tensões, dificuldades, implica conhecimentos, percepção, cumplicidade e conciliação e essa trajetória é muito difícil. Na peça estudada, quando jovem “DonAna"trocou sua carreira profissional pela carreira de esposa e mãe, por restrições da família e da própria sociedade. Octagenária, ela reflete sobre as consequências daquela escolha.

Reforce-se que, na categoria 5, a percepção dos integrantes do grupo focal é a de que o teatro mostrou a convivência entre eles, incorporou novas ideias para elaboração de trabalhos na universidade e os convidou a ser mais comunicativos e desinibidos. Tal percepção encontra-se apoiada em Davel et al. (2007), quando afirmam que a dimensão estética do ensino-aprendizagem da administração engaja as pessoas em suas experiências sensíveis, como as sensoriais, sensuais e cognitivas.

Ainda nessa categoria pode-se observar o alinhamento da percepção dos discentes com Magalhães, et al. (2004), ao afirmarem que os interesses vocacionais se desenvolvem, usualmente, a partir de experiências de vida reforçadoras do gosto dos indivíduos por determinadas modalidades de atividades em detrimento de outras.

Sinalize-se que, na categoria 6, o grupo focal refletiu sobre a necessidade precoce de cuidar da formação profissional e de um plano de carreira, uma vez que, em suas percepções, as pessoas com idade mais avançada estão sendo excluídas do mercado de trabalho. Por um lado, esses discentes lembraram o que foi dito por Beres (2002), a respeito do modo como uma pessoa aposentada é tratatada pela sociedade que a qualifica como velha. Por outro lado, o conceito de Cachioni \& Neri (2004) acerca da velhice produtiva mostra que as pessoas com idade mais avançada excedem os limites da atividade economicamente produtiva e do trabalho. Na visão de Magalhães, Krieger, et a/ (2004) o isolamento social, determinado pelo meio social, leva ao envelhecimento. O que os discentes trouxeram, nessa categoria, pode ser compreendido como um cuidado pertinente para evitar esse isolamento social.

\section{Considerações Finais}

Em observância aos aspectos contidos na indissociabilidade, entre ensino, pesquisa e extensão, a investigação feita por intermédio desta pesquisa apontou a contribuição do teatro para o processo de ensino-aprendizagem em Administração em cada uma das vertentes.

No que tange à vertente do ensino considera-se que os discentes foram co-responsáveis pela interpretação das mensagens trazidas pela ação da personagem da peça "DonAna" no que tange à reflexão sobre a trajetória de carreira, o envelhecimento das pessoas e o mercado de trabalho.

Nessa vertente, o processo foi desenvolvido com a participação de 484 discentes em 2010 e 292 em 2011, do curso de Administração de Recursos Humanos de uma universidade privada da cidade de São Paulo. A arte pôde trazer um novo olhar para a educação em Administração, tanto para os docentes / pesquisadores, quanto para os discentes, em suas práticas em sala de aula.

Na vertente da pesquisa, investigando a contribuição do teatro para o processo de ensino-aprendizagem em Administração, a pergunta ficou respondida com a arte podendo suscitar reflexões em Administração, tanto para os docentes / pesquisadores, quanto para os 118 dos 292 discentes que participaram, em 2011, da vertente do ensino. Suas práticas de fazer e responder pesquisas que versem, simultaneamente, sobre temátca de gestão de pessoas e processo de ensino-aprendizagem marcaram, para muitos deles, o início de suas atuações nessa vertente.

Na vertente da extensão o autor / ator da peça "DonAna", quando entrevistado, declarou que os envolvidos com ela, no teatro, reiteram a importância do aprendizado obtido com esses docentes / pesquisadores, os 484 discentes em 2010 e os 292 em 2011, enfatizando o modo como eles vêm 
contribuindo, também, com a perspectiva do autor / ator sentir sobre as pessoas nas organizações, suas carreiras, o mercado de trabalho e a preparação para a velhice.

Considerando-se as fontes de evidência utilizadas com os discentes, nesta pesquisa, foram registrados depoimentos sobre: a importância de valorizar os sonhos para não se frustrarem na velhice; elogios à iniciativa dos professores da universidade; valorização sobre essa outra forma de aquisição do conhecimento; solicitação de outros espetáculos em que os discentes pudessem ser convidados; a importância do teatro para o crescimento pessoal e profissional; valorização da interação entre as pessoas nessa atividade, dentro e fora dos muros da universidade.

\section{Referências}

Abbs, P. (1994). The educational imperative: a defense of Socratic and aesthetic learning. Washington DC: The Falmer Press.

Almeida, M. J. (2004). Imagens e sons: a nova cultura oral. São Paulo: coleção Questões da Nossa Época, n. 32, Cortez.

Araújo, A, P.; Alburquerque, L. G.; Silva, L. M. T. (2009). Mercado de trabalho e gestão de pessoas:

mudanças e desafios. In: Alburquerque, L. G.; Leite, N. P. Gestão de pessoas: perspectivas estratégicas, pp. 55-70. São Paulo: Atlas.

Arthur, M. B.; Rousseau, D. M. (Eds.). (1996). The boundaryless career: a new employment principle for a new organization era. Oxford: Oxford University Press.

Balassiano, M.; Ventura, E. C. F.; Filho, J. R. F. (2004). Carreiras e cidades: existiria um melhor lugar para se fazer carreira? Revista de Administração Contemporânea, 8 (3), 99-116.

Bardin, L. (2010). Análise de conteúdo. Lisboa: Edições 70.

Beres, V. L. G. (2002). Quando nos tornamos velhos. São Paulo: Vetor.

Bianchi, E. M. P. G.; Quishida, A. (2009). Gestão estratégica de carreiras. In: Alburquerque, L. G.; Leite, N. P. Gestão de pessoas: perspectivas estratégicas, pp. 79-95. São Paulo: Atlas.

Brandão, M. S. (2004). Leve seu gerente ao cinema: filmes que ensinam. Rio de Janeiro: Qualitymark.

Cachioni, M.; Neri, A. L. (2004). Educação e gerontologia: desafios e oportunidades. Revista Brasileira de Ciência do Envelhecimento Humano, 99-115.

Carvalho, J. L. F. S. (2007). Estimulando a criatividade e o pensamento crítico: o professor como autor, diretor e dramaturgo. In: Davel, E.; Vergara, S. C.; Ghadiri, D. P.(Org.) Administração com arte: experiências vividas de ensino-aprendizagem, pp. 173-184. São Paulo: Atlas.

Cavassin, J. (2008). Perspectivas para o teatro na educação como conhecimento e prática pedagógica. Revista Científica FAP, 3, 39-52.

Chanlat, J. (1995). Quais carreiras e para qual sociedade? (I). Revista da Administração de Empresas. São Paulo: 35 (6), 67-75, nov./dez..

Chizzotti, A. (2008). Pesquisa qualitativa em ciências humanas e sociais. Petropólis: Vozes.

Cooper, D. R.; Schindler, P. S. (2003). Métodos de pesquisa em Administração. Porto Alegre: Bookman.

Costa, A. S. (2004). Teatro, educação e ludicidade: novas perspectivas em educação. Revista da FACED, 8, 94-108.

Davel, E.; Vergara, S. C.; Ghadiri, D. P. (2007). Administração com arte: papel e impacto da arte no processo de ensino-aprendizagem. In: Davel, E.; Vergara, S. C.; Ghadiri, D. P. Administração com arte: experiências vividas de ensino-aprendizagem, pp. 13-26. São Paulo: Atlas.

Davel, E.; Vergara, S.; Ghadira, S.; Fischer, T. (2004). Revitalizando a relação de ensino-aprendizagem em administração por meio de recursos estéticos. Paper presented at the XXVIII EnANPAD. Curitiba.

Debert, G. G. (2004). Reinvenção da velhice. São Paulo: EDUSP.

Dewey, J. (1934). Art as experience. New York: Perigee Books.

Duarte, R. (2002). Cinema e educação. Belo Horizonte: Autêntica.

Dutra, J. S. (2002). A gestão da carreira. In: Fleury, M. T. L. (Org.). As pessoas na organização, pp. $99-114$. São Paulo: Gente. 
Carreira, mercado de trabalho e as lições de "DonAna" no processo de ensino-aprendizagem e pesquisa em administração

Dutra, J. S. (2011). Gestão de pessoas: modelos, processos, tendências e perspectivas. São Paulo: Atlas. Evans, P. (1996). Carreira, sucesso e qualidade de vida. Revista de Administração de Empresas. 36 (3), 14 22. São Paulo: FGV.

Gatti, B. A. (2005). Grupo focal nas pesquisas em ciências sociais e humanas. Brasília: Liber Livro.

Goodman, N. (1976). Languages of art: an approach to a theory of symbols. Indianapolis: Hackett.

Ipiranga, A. S. R. (2007). A narração fílmica no ensino de gestão de pessoas e de comportamento organizacional. In: Davel, E.; Vergara, S. C.; Ghadiri, D. P. (Org.) Administração com arte: experiências vividas de ensino-aprendizagem, pp. 81-91. São Paulo: Atlas.

Kind, L. (Jun./2004). Notas para o trabalho com a técnica de grupos focais. Psicologia em Revista, 10 (15), 124-136. Belo Horizonte.

Koudela, I. D.; Santana, A. P. (2005). Abordagens metodológicas do teatro na educação. Ciências Humanas em Revista, $3(2), 145-154$. São Luis.

Leite, N. R. P.; Leite, F. P. (2007). Um estudo observacional do filme Denise Está Chamando à luz da teoria de ação de Chris Argyris e Donald Schön. Revista de Gestão da USP, 14 (Especial), 77-91.

Leite, N. R. P.; Leite, F. P. (2010). A linguagem fílmica na formação e no fortalecimento de grupos, equipes e times de trabalho: aplicações do estudo observacional. In: Revista de Gestão da USP, 17(1), 75-97.

Leite, N. R. P.; Leite, F. P. Nishimura, A. T.; Cherez, R. L. (2010). Educação tutorial: revitalizando ensinoaprendizagem e pesquisa em administração. Revista Adm. FACES Journal, 14 (4), 87-104.

Leite, N. R. P.; Nishimura, A. T.; Leite, F. P. (2010). O estudo do construto amor em Administração: ciência ou senso comum? Revista REUNA, $15(2), 59-81$.

London, M.; Stumph, S. A. (1982). Managing careers. Reading: Addison-Wesley.

Luckesi, C. C. (2002). Ludicidade e Atividades Lúdicas - uma Abordagem a partir da Experiência Interna. In Porto, B. de S. (Org.). Ludicidade: o que é mesmo isso? Salvador: Faced/PPGEDU.

Magalhães, M. O.; Gomes, W. B. (2005). Personalidades Vocacionais, generatividade e carreira na vida adulta. Revista Brasileira de Orientação Profissional, 6(2), 71-80.

Magalhães, M. O.; Krieger, D. V.; Vivian, A. G.; Straliotto, M. C.; Poeta M. P. (2004). Padrões de ajustamento na aposentadoria. Revista Aletheia, 19, 57-68.

Magalhães, M. O.; Martinuzzi, V.; Teixeira, M. A. P. (2004). Relações entre estilos cognitivos e interesses vocacionais. Revista Brasileira de Orientação Profissional, 5 (2), 11-20.

Mattos, P. L. C. L. (2006). Os resultados de minha pesquisa qualitativa não podem ser generalizados: pondo os pingos nos is dessa ressalva. Paper presented at the XXX EnANPAD. Salvador.

Mattos, P. L. C. L. (2009). “Administração é ciência ou arte?" O que podemos aprender com este mal entendido? Revista de Administração de Empresas, 3 (49), 349-360. São Paulo: FGV.

Monteiro, P. P. (2005). Envelhecer: histórias, encontros, transformações. Belo Horizonte: Autêntica.

Morgan, D. L. (1997). Focus groups as qualitative research. London: SAGE Publications.

Napolitano, M. (2009). Como usar o cinema na sala de aula. São Paulo: Contexto.

Offe, C.; Hinrich, K. (1984). Economia social do mercado de trabalho: diferencial primário e secundário de poder. In: Offe, C. Trabalho \& Sociedade: problemas estruturais e perspectivas para o futuro da sociedade do trabalho. Rio de Janeiro: Edições Tempo Brasileiro.

Oliveira, M; Freitas, H. (2006). Focus groups: instrumentalizando o seu planejamento. In: Godoi, C. K.; Bandeira-de-Mello, R.; Silva, A. B. (Orgs.). Pesquisa qualitativa em estudos organizacionais - paradigmas, estratégias e métodos, pp. 325-346. São Paulo: Saraiva.

Powell, R. A.; Single, H. M. (1996). Focus groups. International Journal for Quality in Health Care, 8(5), 499505. http://dx.doi.org/10.1093/intqhc/8.5.499. PMid:9117204

Richardson, R. (1989). Pesquisa social: métodos e técnicas. São Paulo: Atlas.

Taylor, S. S. (2007). Experimentando diferentes modos de conhecimento por meio da improvisação teatral. In: Davel, E.; Vergara, S. C.; Ghadiri, D. P. (Orgs). Administração com arte: experiências vividas de ensinoaprendizagem, pp. 185 - 194. São Paulo: Atlas.

Vergara, S. C. (2003). Repensando a relação ensino-aprendizagem em Administração: argumentos teóricos, páticas e recursos. Organizações \& Sociedade, $10(28)$. 
Vergara, S. C. (2005). Métodos de pesquisa em administração. São Paulo: Editora Atlas.

Vergara, S. C. (2007). Arte cenográfica, vídeos, dramatizações e música no ensino de teoria das organizações. In: Davel, E.; Vergara, S. C.; Ghadiri, D. P. (Orgs). Administração com arte: experiências vividas de ensino-aprendizagem pp. 277 - 286. São Paulo: Atlas.

Vergara, S. C.; Davel, E.; Ghadiri, D. P. (2007). Concluindo - Arte no ensino de administração e administração com arte. In: Davel, E.; Vergara, S. C.; Ghadiri, D. P.(Orgs). Administração com arte: experiências vividas de ensino-aprendizagem pp. 287 - 290. São Paulo: Atlas.

Wood Jr., T. (2000). Metáforas espetaculares: do dramatismo teatral ao dramatismo cinematográfico. Paper presented at the XXIV EnANPAD. Florianópolis. 